\title{
Determinants of Mispricing on
}

\section{Indonesian Sovereign Sukuk Auction}

\author{
Ristiyanti Hayu Pertiwi \\ Islamic Economics Undergraduate Program \\ Faculty of Economics and Business, Universitas Indonesia \\ Depok, Indonesia \\ risti.hayu@gmail.com
}

\author{
Tika Arundina \\ Islamic Economics Undergraduate Program \\ Faculty of Economics and Business, Universitas Indonesia \\ Depok, Indonesia \\ tikarundina@gmail.com
}

\begin{abstract}
Common Value Theory points out the situation in financial instrument auction where investors tend to bid a lower price than the actual value and it results in an underpricing of financial instrument. The underpricing, further, may hamper the market as it leads to revenue loss for the company. As the Islamic financial market developed, government of Indonesia expands their instrument variations and started to issue Islamic Bond (sukuk) in 2008. There is still lack of empirical literature relating to sukuk pricing performance although sukuk has several distinct features such as the existence of underlying asset. This paper attempts to examine the underpricing indication in sukuk issuance during 2012-2016 and analyze the factors that might explain its persistence. To examine the existence of sukuk underpricing issuance, this study uses yield spread from weighted average yield when auction and market yield when auction. To this end, Ordinary Least Square model is applied to analyze the determinants of underpricing. In contrast to the theory, the result shows that average sukuk issuance in Indonesia indicates a higher market yield than weighted average yield when auction.
\end{abstract}

Keywords—sukuk, auction, underpricing, overpricing

\section{INTRODUCTION}

The development of the Islamic finance industry has prompted the government to publish state budget financing instruments in accordance with the principles of sharia. The instrument is named sukuk which derived from Arabic sakk with the plural of sukuk. In short, sukuk can be interpreted as a document or certificate. In term, sukuk refers to some contemporary definitions. The Accounting and Auditing Organization for Islamic Financial Institutions (AAOIFI) defines sukuk as a certificate of equal value that represents an undivided share of an intangible asset, the value of the asset (usufruct), and services (services), or the asset ownership of a project or certain investment activities. Meanwhile according to Financial Services Authority of Indonesia (previously Capital Market Supervisory Agency), sukuk is a certificate of equal value that represents an undivided share of tangible assets, usufruct value, services, and asset ownership of a particular project or investment activity. Sukuk Negara Republik Indonesia or Indonesian sovereign sukuk was first issued by the government in 2008 as a public finance instrument. This new instrument is expected to help reducing government budget deficit, which in turn is also expected to have a positive impact on the national economic growth.

Sovereign sukuk is issued by Ministry of Finance using three methods: book-building, private placement, and auction. During the fourth quarter of 2009, government issued sukuk through the auction system for the first time. Several bidders from bank institutions, security companies, Bank Indonesia, and deposit insurance corporations actively participated in the event. The series sold in this auction were Sukuk IFR001 and IFR002. The auction was then held regularly in 2010 with various maturity offered in response to the potential demand from investors. For a year, sovereign sukuk was auctioned approximately 13 times with total issuance of IDR 16.5 trillion. Today, sovereign sukuk auction is carried out in accordance with Government calendar of issuance which is determined yearly [1].

As sukuk is commonly seen as substitute to sovereign bond, it has some similar financial character issues within them. During the auction process, each bidder in auction tends to sell back the assets that have been acquired. This behavior raises the expectation of an increase in future selling price that occurs in the market (common value) resulting in a fall in the offer price at the time of the auction. One of the first empirical studies of this common value theory was conducted in the United States and shown that the price of bonds when traded on market after the auction was higher than the price in the primary market or at the time of the auction [2]. In addition, complementary research found indications of decline in US government bond prices in the secondary market on the week of the auction, but the bond prices rose again in the week after [3]. Meanwhile in Indonesia, it was found that the average underpricing potential of issuing Government Bonds namely Surat Utang Negara (SUN) FR series through auction in the primary market reached $0.58 \%$ or $58 \mathrm{bps}$ (base point) during the period of 2005-2009. Price changes from auction time to settlement indicate that the potential of government revenue could increase by IDR 1.18 trillion to IDR 204.687 trillion. The difference is the potential for revenue loss as a result of underpricing at the time of the auction [4].

Research upon underpricing in Indonesian sovereign sukuk is urged to be done because it might reflect their performance from pricing aspect. Until now, it is still rare to find research 
on underpricing in the issuance of sukuk either in Indonesia or within the international research. Thus, this study is expected to contribute to the study of sukuk as a public finance instrument in Indonesia and complement the literature on sukuk. In addition, the final result of this study can be used as a reference and recommendation for the government in determining the variables of the price and benchmark yield of sukuk auction, both from a financial and economic point of view. It also acts as complementary literature to the assumption of random walk that has been used by the government in preparing the benchmark of sovereign sukuk auction price in Indonesia. Further, it is also useful for investors and bidders to set their bid price.

\section{LITERATURE REVIEW}

\section{A. Islamic View on Public Financing}

Fiscal policy is the use of government power to adjust the level of expenditure and tax rates in order to monitor and affect a country's economic conditions. In the event of a budget deficit, the government will increase state revenues by increasing loans, raising taxes, or a combination of both. Each policy aims to improve economic growth and stability of the country. The process of formulating such fiscal policy will have consequences on the government's budget position. The Islamic economic system, on the other hand, has a broader concept of fiscal policy than in the conventional economic system. Besides aiming to promote the economic growth, the Islamic economic system also demands the government to reduce the poverty level, reduce the income gap, provide social security, equality of access to resources, and realize sustainable economic growth for future generations. In addition, policies to increase state revenues should be risk-sharing-based, so that debt instruments with interest components should be eliminated. Thus, any financing instruments including public finance has to be backed by asset or usufruct of the asset. Once the event of debt default occurs, the probability of collapse could be minimized. The absence of underlying asset is forbidden [1].

Sukuk as one of the instruments of fiscal policy in accordance with the principles of sharia plays an important role as a public financing instrument, especially in Indonesia. The issuance of sukuk can be arranged in different structures according to the availability of underlying assets and government needs. Since 2011, the government has had a mission to issue sukuk as a project financing instrument. The mission is regulated in Law Number 19 Year 2008 stating that project financing in the framework of the implementation of the State Budget (APBN) can be sourced from the issuance of the State Sukuk. Financing the project in question is the financing that has received allocation in the state budget. Therefore, the government issued project-based Sukuk (PBS) on October 11, 2011. Unlike the other sukuk series, PBS has a direct relationship with the real sectors.

Since the first inception until the year of 2016, there were six projects that had been funded by the Sukuk Negara PBS series. In 2013, the State Sukuk funded the construction of the Cirebon-Kroya double track railway under the Ministry of Transportation with a total project of IDR 800 billion. Further, it also funded the construction of Manggarai-Jatinegara double track railway under the Ministry of Transportation and hajj hostel in some provinces under the supervision of the Ministry of Religious Affairs. From 2015 to 2016, there are also the construction of the Office of Religious Affairs (KUA) and the purchase of infrastructure for Higher Education under the Ministry of Religious Affairs, the construction of railways in Jabodetabek, Central Java and Sumatra under the Ministry of Transportation, and the construction of roads and bridges in under the Ministry of Public Works. The total project in 2015 to 2016 was worth more than Rp 20 trillion [1].

\section{B. Treasury Auction Mechanism in Indonesia}

Auction is one of the methods of issuing and selling securities attended by bidders by proposing competitive bids and/or non-competitive bids within a predetermined bid period of time by bidders. Bidders are coming from various banks and securities company appointed by the Minister of Finance as the auction participant of Sovereign Sukuk Securities (SBSN) in the domestic primary market. SBSN auction participants per December 2016 consisted of 17 banks and 4 securities companies. 17 banks listed as SBSN auction participants are Citibank N.A., Deutsche Bank AG, J.P. Morgan Chase Bank, N.A., PT. Bank BNP Paribas Indonesia, PT. Bank Central Asia, Tbk., PT. Bank CIMB Niaga, Tbk., PT. Bank Internasional Indonesia, Tbk., PT. Bank Mandiri (Persero), Tbk., PT. Bank Negara Indonesia (Persero), Tbk., PT. Bank Negara Indonesia Syariah, PT. Bank OCBC NISP, Tbk., PT. Bank Permata, Tbk., PT. Bank Rakyat Indonesia (Persero), Tbk., PT. Bank Syariah Mandiri, PT. Pan Indonesia, Tbk., Standard Chartered Bank, and The Hongkong and Shanghai Banking Corporation Limited. While securities companies listed as the sukuk auction participants are PT. Bahana Securities, PT. Danareksa Sekuritas, PT. Mandiri Sekuritas, and PT. Trimegah Securities, Tbk.

The bidding format includes the number of units purchased (billion rupiah or thousand units), the desired yield level, and residential status. The bid yield is delivered in a percentage format with five digits numbers behind the comma and is in a multiple of five. The government also imposes a single bid single record, so that each purchase offer is considered as a separate transaction. Awarding of auction winner is conducted by the Director General of Financing and Risk Management which includes the nominal value of SBSN won; the yield or discount rate, and the value of the SBSN asset. This can be either a decision to accept all or part of it, or reject all incoming bids. The considerations used in determining the winning bidder are the proposed price, the time for bidding, volume, and projected future debt risk management. The Ministry of Finance explained the settlement as the settlement of SBSN transactions consisting of fund settlement and SBSN ownership settlement. Fund settlement and ownership settlement are done two days after the auction $(\mathrm{T}+2)$ [5].

\section{Underpricing in Treasury Auction}

As the consequence of the information gap, market participants will be cautious in making decision to invest. As a follow-up to that observation, the first auction of single unit single bid model and multiunit single bid model is developed in formal academic literature [6]. Findings from the model are later known as common value theory, where bidders or 
investors are assumed to have the motivation to gain additional profit; so they try to find a way to maximize their profits even with limited information. This condition will result in underpricing on the common value model. The common value auction model is further developed by some researchers by reducing the tightness of assumption or adding new assumption such as the assumption of a resale market [7], additional risk averse behavior assumptions on investors and market forces influence [8], and private information availability ${ }^{[1]}$.

Various methods are also applied in measurement of underpricing. A research in Finland treasury auction used the difference from secondary market price and stop-out price during the auction time as proxy of underpricing [9], whilst a research in Build America Bonds (BAB) used markup or percentage markup from offered price [10]. Goldreich on his research to determine underpricing in United States Treasury note and bond auction used the differences between yield when auction and yield from another identical bond in secondary market ${ }^{[1]}$. The last method, yield spread, was chosen to be applied in this research.

Studies conducted to analyze the factors influencing bond underpricing have been found in several countries. Determinants primarily go around the issue of credit risk, information spread, bidder competition, and specific event as dummy variable [11].

\section{Methodology}

The data were arranged in cross section data and were obtained through secondary data. The research was carried out by taking 220 auction data over the period of 2012 to 2016. Series auctioned during this period included PBS001, PBS002, PBS003, PBS004, PBS005, PBS006, PBS007, PBS008, PBS009, PBS011, PBS012, PBS013, and PBS014 series. Auction data are public information obtained from the Ministry of Finance through press releases; and are issued before and after the auction process is implemented. The research sample was taken from the auction where the offers received, so that the transaction occurs between investors through auction agent and government. Several sovereign sukuk auctions conducted by the Ministry of Finance do not reach the balance point because of the owner's estimate of the government's inconsistency with the yields that comes in during the bidding. In the end, despite the state's sukuk is offered through the auction, the discrepancies result in the failure of the transaction. On the other hand, there are several auctions that do not end with transactions because no auction agent is willing to bid against the securities being auctioned.

The time span from 2012 to 2016 is taken because during the period government conducted auctions periodically according to the national auction calendar. Besides, in the starting period of 2012, government offered more variations on the sukuk series auctioned off both with new issuance and reopening. The research, further, is specific to analyze the issuance of Project Based Sukuk series although there are two other series which are also issued by auction system namely Islamic Fixed Rate (IFR) and Sharia-State Treasury (SPN-S). The IFR series sukuk is removed from the research sample because it stopped publishing in early 2012. PBS also has a major distinct feature with sovereign bond as it is directly linked with projects as their underlying asset so it is expected to find interesting findings within this series issuance.

Underpricing in Indonesia sovereign sukuk auction is based on the yield spread method [1]. The yield of the country sukuk spreads at each auction is measured as the difference between the weighted average yields on the auction yielded by the yield on the market at the time of the auction. Each auction conducted during the 2012-2016 period has several series of Project Based Sukuk or PBS offered, then the weighted average yield variable is denoted as: $\mathrm{WAY}_{\mathrm{i}, \mathrm{t}}$ with $\mathrm{i}$ as an explanation of the bond series offered at auction date $t$, while the spread is notified as Spreadi,t. Spread is then calculated using its average value and tested the mean-significance using t-test.

$$
\text { Spread }_{i, t}=W A Y_{i, t}-\text { When-issued Market } \text { Yield }_{i, t}
$$

Reference [11] is used for composing the regression estimation as well as several additional modifications of independent variables.

$$
\begin{aligned}
\multicolumn{1}{c}{\text { Spread }_{i, t}=} & \alpha_{0}+\alpha_{1} \mathrm{BAS}_{\mathrm{i}}+\alpha_{2} \mathrm{BTCR}_{\mathrm{i}}+\alpha_{3} \mathrm{CDS}_{\mathrm{i}}+\alpha_{4} \mathrm{USD}_{\mathrm{i}} \\
& +\alpha_{5} \mathrm{JI}_{\mathrm{i}}+\alpha_{6} \mathrm{NEW}_{\mathrm{i}}+\alpha_{7} \mathrm{MTR}_{\mathrm{i}}+\varepsilon_{\mathrm{i}} \\
\text { where } & \\
\alpha_{0}, \alpha_{1}, . ., \alpha_{8}= & \text { Regression parameter (constant) } \\
\text { Spread }_{\mathrm{i}, \mathrm{t}}= & \text { Underpricing (dependent) } \\
\mathrm{BAS}_{\mathrm{i}}= & \text { Bid ask spread before auction (independent) } \\
\mathrm{BTCR}_{\mathrm{i}}= & \text { Auction Bid to Cover Ratio (independent) } \\
\mathrm{CDS}_{\mathrm{i}}= & 10 \text {-years Indonesian CDS premium before } \\
& \text { auction (independent) } \\
= & \text { IDR to USD exchange rate before auction } \\
& \text { (independent) } \\
\mathrm{USD}_{\mathrm{i}} & \text { Jakarta Islamic Index before auction } \\
& \text { (independent) } \\
\mathrm{JII}_{\mathrm{i}} & \text { New Issuance dummy (independent) } \\
\mathrm{NEW}_{\mathrm{MTR}} & \text { Maturity above 10 years dummy } \\
& \text { (independent) }
\end{aligned}
$$

Underpricing determination analysis is done by Ordinary Least Square (OLS) method. OLS analysis method is chosen because the data type of research is cross section with the subject of various auctions that do not have a certain time pattern for each subject. Outputs presented in this paper have been cleared from any heteroscedasticity, multicollinearity, autocorrelation, and normality; so it could fulfill Best Linear Unbiased Estimator assumption [12].

\section{FINDINGS AND DISCUSSION}

The Government of the Republic of Indonesia through the Ministry of Finance held 339 times sukuk country Sukuk series project-based Sukuk in total of 101 days of implementation in the period of 2012-2016. Through the auction, the government offered Sukuk PBS with a total offer of IDR 366.23 trillion. Based on the same data, there was more IDR 164.3 trillion financing successfully transacted or about $44.8 \%$ of total incoming bids. In this case, the government rejected several offers submitted by bidders because they did not comply with 
the personal parameters that had been formulated by the Ministry of Finance. However, at the start of 2012 and 2013 publications, the country's sukuk series auction of PBS received only a few offers from bidders so that many of the auctions were canceled. The trend of auction implementation from 2012 to 2014 showed a downward trend, although from 2015 to 2016 the number increased. By percentage, the trend of the number of bids received compared to the number of auctions increased. In 2012, only about $37 \%$ of the auctions were accepted. This number increased subsequently in the following year by $64 \%, 83 \%$, and $90 \%$. Of the total 339 auctions held by the Ministry of Finance, only 220 data fell into the category of research scope.

\section{A. Mispricing: Undepricing or Overpricing}

Prior to processing, it is necessary to test outliers on the main data directly related to the auction of Yield Spread and Bid to Cover Ratio (BTCR). Data outliers are data that have significant differences with other data. Unidentified data outliers will disrupt the hypothesis testing process and can lead to biased conclusions. Testing is done by method of data standardization using value of $\mathrm{z}$ [13].

Standardization of data using the $\mathrm{z}$ value is the most commonly used method for detecting data anomalies. Data with $\mathrm{z}$ values below -3 or above 3 should be drawn from the sample. Calculation of $\mathrm{z}$ value for each data using the formula of $z=\frac{x-\bar{x}}{\sigma}$. In the Spread and BTCR variables, each of them has three data that become outliers so that there are total of five auction data that must be removed from the research sample. Data outliers on Spread variables are in the PBS008 series auction on January 13, 2015 and PBS011 dated April 16,2016 . While the data on the BTCR variable are available on PBS001 series auction on August 7, 2012, PBS006 dated March 11, 2014, and PBS012 dated August 23, 2016.

The existence of underpricing will be determined from significance value of the yield spread on the auction of PBS sovereign sukuk during 2012-2016. The significance of the mean values is calculated by comparison of the statistical $t$ and $t$ critical values in each category. A positive value on the mean of yield spread means to indicate underpricing and vice versa. The test is performed by testing the underpricing first (righttailed t-test). If there is an overpricing indication, a second $t-$ test with left-tailed hypotheses is performed.

TABLE I. T-TEST ON SOVEREIGN SUKUK UNDERPRICING (RIGHT-TAILED T-TEST IS APPLIED TO POSITIVE YIELD SPREAD AND LEFT-TAILED FOR NEGATIVE YIELD SPREAD. SIGNIFICANCE LEVEL IS VARIED FROM *) $1 \%$, **) $5 \%$, AND ***) $10 \%$ )

\begin{tabular}{l|ccccccc}
\multirow{2}{*}{ Kategori } & \multirow{N}{*}{$\boldsymbol{N}$} & Mean & \multicolumn{3}{c}{ Tabel t-Stat } & \multicolumn{2}{c}{ Mean } \\
\cline { 4 - 8 } 2012 & & & $\mathrm{~T}_{10 \%, \mathrm{df}}$ & $\mathrm{T}_{5 \%, \mathrm{df}}$ & $\mathrm{T}_{1 \%, \mathrm{df}}$ & $\mathrm{t}-$ Stat & Sig. \\
2013 & 35 & -0.458 & -1.307 & -1.691 & -2.441 & -5.561 & $* * *$ \\
2014 & 26 & 0.132 & 1.316 & 1.708 & 2.485 & 2.801 & $* * *$ \\
2015 & 29 & 0.083 & 1.312 & 1.701 & 2.467 & 1.876 & $* *$ \\
2016 & 54 & 0.021 & 1.298 & 1.674 & 2.399 & 0.045 & \\
$2012-2016$ & 71 & -0.079 & -1.294 & -1.667 & -2.380 & -2.723 & $* * *$ \\
& 215 & -0.068 & -1.286 & -1.652 & -2.344 & -2.764 & $* * *$
\end{tabular}

Source: Author Calculation
Underpricing in Indonesian Sovereign Sukuk Auction was found significantly occurring in 2013 and 2014 (see Table 1). It might happen particularly to the increase of Indonesian credit risk as response to downfall in world economic. Indonesia experienced a high inflation at the moment, pushing back the investor desire to trade in market, thus resulted in a lower awarded price when auction than the actual price in secondary market.

During the year of 2012, 2016, and simultaneously 20122016, it was indicated that there was a lower awarded yield in auction than the market yield. This finding might be a sign that there was overpricing in the auction because sovereign sukuk investor did not follow common value theory behavior. Investors who sought profit in secondary market would likely to ask a higher yield in auction compared to market yield so it could maximize their return. Compared to the finding in sovereign bond auction [4], overpricing in sukuk was beneficial for positive state revenue and indicated a better pricing performance than its substitute. It can be concluded that the existence of underlying asset in sovereign sukuk plays an important role to increase the confidence level of investors to keep buying sukuk although it is overpriced.

\section{B. Mispricing Determinant}

To determine the factors which might influence the mispricing, an analysis on Indonesian sovereign sukuk auction is conducted. Yield spread as the proxy of mispricing will be used as dependent variable, while several financial indicators are used as independent variables as written in equation (2) model. It is then adjusted using result of regression process in Table 2.

TABLE II. Mispricing DETERMINANTS ON SOVEREIGN SUKUK AUCTION (SIGNIFICANCE LEVEL IS VARIED FROM *) $1 \%, * *$ ) $5 \%$, AND ***) $10 \%$ )

\begin{tabular}{ccc}
\hline \multirow{2}{*}{$\begin{array}{c}\text { Independent } \\
\text { Variable }\end{array}$} & \multicolumn{2}{c}{ Regression-1 } \\
\cline { 2 - 3 } $\mathbf{C}$ & -10.65723 & $-1.983934^{*}$ \\
\hline BAS & 6.50151 & $3.019947^{* * *}$ \\
\hline BTCR & -0.03064 & $-2.332823^{*} *$ \\
\hline Log(CDS) & 0.52989 & 0.950530 \\
\hline Log(USD) & 0.04973 & 0.096489 \\
\hline Log(JII) & 1.13409 & 1.284975 \\
\hline NEW & -0.27422 & $-1.806250 *$ \\
\hline MTR & 0.01064 & 0.183512 \\
\hline \multicolumn{2}{c}{ Sample (N) } \\
\hline Adj R-Squared \\
\hline F-Statistic \\
\hline Prob(F-statistic)
\end{tabular}

Source: Author Calculation

Rewritten as:

$$
\begin{aligned}
\text { Spread }_{i, t}= & -10.65^{*}+6.50 \mathrm{BAS}_{\mathrm{i}} * * *-0.03 \mathrm{BTCR}_{\mathrm{i}} * * \\
& +0.52 \log (\mathrm{CDS})_{\mathrm{i}}+0.05 \log (\mathrm{USD})_{\mathrm{i}}+ \\
& 1.13 \log (\mathrm{JII})_{\mathrm{i}}-0.27 \mathrm{NEW}_{\mathrm{i}}^{*}+0.01 \mathrm{MTR}_{\mathrm{i}}+\varepsilon_{\mathrm{i}}
\end{aligned}
$$

The level of liquidity in the secondary market prior to the announcement of the auction plan, which is proxied by the BAS variable, may explain the occurrence of the underpricing 
level. The more bid-ask spreads nominal at the auction date, the higher the underpricing level because the expectation of asset sale price will be lower [7]. This also indicates that the majority of bidders are traders who trade on volatility while maintaining liquidity and spreading bid prices to maximize profits and ease the sales price after the auction in order to participate in the next auction [1].

Bidding to cover ratio as the proxy of auction competitiveness showed a negative correlation with underpricing. It is consistent with previous findings where the increase of bidding participants would decrease their individual bids because they have target to buy specific target amount of sukuk to be hold, regardless the yield [1]. It is an interesting finding; it might be concluded that sovereign sukuk is appealing to bidder as they choose to lower the yield instead of walking out the auction.

Last, the dummy variable of new issuance showed a significant negative impact on underpricing. This variable was constructed using dummy, where 1 defines as new issuance and 0 is reopening auction. Negative sign shows that underpricing more likely occurs in reopening auction, whereas new issuance of sukuk indicates a less underpricing. This finding is contrary to several events in stock underpricing because majority of stock IPOs experienced a high underpricing [14]. It happened because investors saw IPO stock as high risk instrument as they had no benchmark performance beforehand. Thus, despite the high risk, investors still put their confidence in sovereign sukuk, resulting in a new issuance overpricing. But this condition is not fully indicating a good pricing performance. A high valuation in IPOs most likely cannot be sustained and there would be market pressure to decrease the value into their intrinsic value [15].

The rest of variables did not significantly affect sovereign sukuk underpricing, such as Indonesian credit risk proxied by CDS, rupiah to US dollar exchange rate, Jakarta Islamic Index as Islamic capital market indicator, and maturity dummy.

\section{CONCLUSION}

Underpricing is a common phenomenon on financial instrument issuance as investors seek to maximize their profit in secondary market. Underpricing in Indonesian Sovereign Sukuk Auction was found significantly occurring in 2013 and 2014. It might happen particularly to the increase of Indonesian credit risk as response to downfall in world economic. Meanwhile during the year of 2012, 2016, and simultaneously 2012-2016 issuances, it indicated that there was a lower awarded yield in auction than the market yield. This finding might be a sign that there was overpricing in the auction where investors did not follow common value theory behavior. It could happen due to the existence of underlying asset in sukuk as instrument backup which the other instrument does not have.

The level of liquidity in the secondary market prior to the announcement of the auction plan, which is proxied by the BAS variable, might explain the occurrence of the underpricing level. Beside liquidity, auction competitiveness also shows a significant influence on underpricing in Indonesia sovereign sukuk auction. But, contrast to the previous research on financial instrument mispricing, new issuance on Indonesia sovereign sukuk auction shows a negative correlation to underpricing.

Further research using qualitative method is necessary to be done to capture the investors and government perspectives in this finding. Overpricing is better than underpricing as it benefits the state revenue, but high valuation in primary market most likely cannot be sustained and there will be market pressure to decrease the value into the intrinsic value.

\section{REFERENCES}

[1] Ministry of Finance, Sukuk Negara: Instrumen Keuangan Berbasis Syariah. Jakarta: Ministry of Finance, 2015

[2] D. Goldreich, "Underpricing in Discriminatory and Uniform-Price Treasury Auctions," The Journal of Financial and Quantitative Analysis, vol. 42, no. 2, pp. 443-466, June 2007

[3] M. J. Fleming and J. V. Rosenberg, "How Do Treasury Dealers Manager Their Positions?" Federal Reserve Bank of New York Staff Reports, no. 299, August 2007 revised March 2008

[4] H. Passagi, Determinan Tekanan Harga pada Lelang Obligasi Negara di Indonesia. Depok: Universitas Indonesia, 2011

[5] Ministry of Finance, Buku Saku Direktori Peserta Lelang SBSN. Jakarta: Ministry of Finance, 2016

[6] W. Vickery, "Counterspeculation, Auctions, and Competitive Sealed Tenders," The Journal of Finance, vol. 16 issue 1, pp. 8-37, March 1961

[7] S. Bikhchandani, P. L. Edsparr, and C. Huang, The Treasury Bill Auction and the When-Issued Market: Some Evidence. Carolina: Nabu Press, 2011

[8] J. J. D. Wang and J. F. Zender, "Auctioning Divisible Goods," Economic Theory, vol. 19 no. 4, pp. 673-705, Jun 2002

[9] M. Keloharju, K. G. Nyborg, and K. Rydqvist, "Strategic Behavior and Underpricing in Uniform Price Auctions: Evidence from Finnish Treasury Auctions", The Journal of Finance, vol. LX no. 4, August 2005

[10] D. Cestau, R. C. Green and N. Schurhoff, "Tax-Subsidized Underpricing: Issuers and Underwriters in the Market for Build America Bonds," prepared for Carnegic Rochester NYU Conference Series on Public Policy, October 2012

[11] B. Aronsson and D. Tano, On Determinants of Underpricing in Corporate Bond Offerings. Sweden: Lund University

[12] D. N. Gujarati, Basic Econometrics $4^{\text {th }}$ Ed. New York: McGraw-Hill Education, 2004

[13] S. Jaggia \& A. Kelly, Business Statistics: Communicating with Numbers $2^{\text {nd }}$ Ed. New York: McGraw-Hill Education, 2015

[14] S. Katti and B. V. Phani, "Underpricing of Initial Public Offering: A Literature Review", Universal Journal of Accounting and Finance, vol. 4(2), pp. 35-52, 2016

[15] K. S. Haggard and Y. Xi, "IPO Overvaluation and Returns Prior to Lockup Expiration,” Managerial Finance, vol. 43 issue 12, pp. 13921410, September 2017 